\title{
Sabang Free Port 1962-1985, Indonesia
}

\author{
Maryana Malik ${ }^{1}$, Suprayitno ${ }^{1}$, Ratna $^{1}$

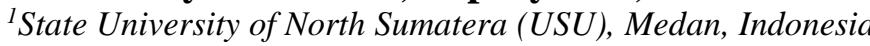 \\ nisanaceh@gmail.com
}

\begin{abstract}
The port was initially only an exile area that turned into a port reckoned in Aceh. In addition, Sabang Port was one of the transito ports that survived only during the Colonial period of the Netherlands. Sabang Port in the time of independence was functionalized as an import-export port. The review uses historical methods in its research process. On the source collection process, sources are used in the form of colonial archives, reports, books, thesis and field studies in the form of interviews on the activities of portage in the Port of the Sabang. The review aims to explain the existence and activity of the Port of Sabang. To support such purposes it was also described the general conditions of Sabang Port during colonial times and Sabang Port conditions in the time of independence.
\end{abstract}

Keywords : port; export-import; Sabang.

\section{Introduction}

Strategic areas, such as maritime areas, constitute the entrance or gateway of commodities and humans that can be indicators of social, economic and tourism development. This activity became very important to the development of a region, both to support the territory that was inland and around the ocean. One is the city of Sabang which has an interesting history. Especially if it is associated with a free port, then it is one of the golden ages of the city of Sabang.

The development of the Sabang began with the formation of the port in the Dutch colonial period of 1896. The establishment of this port held an important role as it could bring changes, it was seen when the merchants entered, they not only offered merchandise, but also to enjoy the beauty of nature. In this time export and import activity experienced a very drastic increase, and also increased economic activity in other ports. Many traders began to re-activity, such as the economic jenggo or commonly referred to as the whine. Not only did the merchants enter the Sabang area, but many of the tourists came to enjoy the natural there.

However, this brilliance did not last long. In 1985, the Sabang free and free trade port was closed by the government due to the rife of smuggling and opening of Batam as a free port and as an industrial area. As a result of this, the pit experienced a slump in its activity, as did the area opposite the Sabang. The study was intended to explain how the Sabang free port was during the independence period. However, before getting the idea to review it, previous studies have discussed in detail how the Sabang port was formed until it became a free Port and how this port dimmed, This we can see on the writings of Jusuf Walad discussing the port entitled Ports in Daerah Istimewa Aceh, in this book explains how hinterland ports that conduct trade, tourist and other activities against the Sabang.

Later written by Syamsuddin Mamud, et al., entitled Sabang Free Port 1967, in this book explains how Sabang was during the time of the establishment of a free port by the Indonesian government in 1962. However, this book is a generally described account of how the picture of the wedge was in its time. In the thesis written by M.Yusuf Rangkuti, titled Sabang (19451965) discusses how the development of the Sabang in the time of independence to the time of democracy was led, in this writing also discusses about free ports but is not written in detail how the port made the city of Sabang a port city. Beside from the book described above, there are several books relating to the history of the port of Sabang not much to discuss about the port city, only a few writing but not being reviewed in detail. 


\section{Method}

This article uses historical methods, in historical methods using four stages. In the first stage (heuristic) constitutes a search or data collection stage using two methods, namely data collection through centrality research (library research), archival studies and observations directly visiting locations and by interview. Source collection on Sabang port, Sabang city, community and related development of trade in Sabang port which has been in can from National Archives of Republic of Indonesia (ANRI), Archives of the region in Archives Agency And Library of Nanggroe Aceh Darussalam Province. In this archival study, the author collected the most important of these studies is the one related to Sabang Port which is the archive of Burgelijke Openbare Welken (BOW), Algemeene Secretarie, Secretariat of State of the Republic of Indonesia (Sekneg RI), The Regional Secretariat (Setwilda). Data collection with field research is conducted with port observations in Sabang such as visiting CPC offices (Sabang Area Enterprise Agency), syahbandar offices and Sabang ports. ${ }^{1}$ Besides that in field studies, researchers conducted interviews of several informants, particularly informants directly related to port activity, who understood how the ports were progressing and about the city of Sabang. As for the interviewed namely, Ramli, Elvi, M. Ilyas, Hendra Setiawan, Bustana, Ridwan K.S, Marwan Sulaiman, Abu Bakar Sidik, Ibrahim.

After collecting sources, the second stage is the source criticism stage, to obtain truth factors, the authenticity of the data or the facts obtained. In this stage, the author will perform the process of preparing the study by reading critically to sources that have been collected to search for and obtain the authenticity of the source in terms of both the material and substantially. Then conduct intern criticism and criticism extern. Extern criticism determines that the documents we face are the documents we seek, then intern krtitic proves that the testimony provided by the source is indeed trustworthy. Crosscheck is one thing that can be used to obtain data validity. Thus, the author will receive insight and a pem.

\section{Discussion}

\subsection{Sabang Port Before Set as Free Port}

The beginning of the formation of the port of Sabang was during the reign of the Netherlands. The initial purpose of forming the port was to make it easier for the Dutch government's move to take control of the Sabang area and also as its halfway place or transit ships to fill coal originating from the Ombilin coal mines in West Sumatra.

The port also provides fuel oil delivered from Palembang ${ }^{2}$ and provides other needs. In 1896 the port of Sabang was designated as Free Port ${ }^{3}$ (Vrij-Haven/Free Port) " SABANG MAATSCHAPPIJ ". The opening of the Free Port of the Sabang was originally orientationd

\footnotetext{
${ }^{1}$ Ibid., P: 16.

2 M.G. De Boer, Zeehaven en Kolenstation Sabang 1899-1924, Amsterdam: vervaardigd door L.Van Leer \& CO, 1924 , pp. 7.

${ }^{3}$ The free port is a port freed from customs surveillance by the government for special reasons. The free port does not include a tax area for a country. Ships from any country may enter and make a good deal without duty payments in and out. If goods through the border of the port are free to head into the inland areas, it has only been subject to duty and excise. See Hasan Shadily, Indonesian Encyclopedia, Volume 7. Jakarta: PT Ichtiar Baru van Hoeve, 1999, pp. 352.
} 
towards providing the "coal" fuel required by steam-engined sea-ships. In further development the Sabang was an important and fairly busy "Trading Area" at that time. ${ }^{4}$

The state of the Sabang became crowded with ships before departing for Europe, first a stopover in the Sabang to fill the purposes of oceanic shipping. Japan began its entry into Indonesia to expand its dominions to conquer Dutch rule, hence the switching of Dutch power to Japanese rule. Second World War in 1942 with the Japanese entry into the Aceh and Sabang 5 regions, the state of the Sabang porac and heavily damaged, consequently the Sabang free port was closed by the Japanese ${ }^{6}$ side. Since 1945 , the port has been re-employed to be able to operate as it originally was. After independence, and after the Sabang area passed through the crisis, the Indonesian government began to pay attention to the importance of maritime areas in terms of increased development of the city. One of them Sabang was made a madya city, which was thought to have been able to govern its area. ${ }^{7}$ However until the 1960s, it was only that the port regained its status as a free port.

After the establishment of free port status was granted to Sabang, then port activity began to be reconstituted, that is, conducting trade. The development of a port could also not be released from the activity of the opposite area/foreland especially the areas of commerce and shipping. Because the opposite area offers product results as well as being able to increase the influx of the flow of ships into the Sabang area. Slowly the activities of the Sabang port began to be crowded in sojourn by ships from abroad as well as from within the country. This activity made the city of Sabang resurrect after it was destroyed by the Japanese, infrastructure and economic improvements have also made the city better. The greater the mobility of people therefore enters into a region then the more economic activity develops in that place. Port life makes Sabang more alive because of trade, workers, services, and other activities. Aside from being the leaning place of ships in the Sabang, as mentioned earlier regarding this city was known for its natural beauty thus bringing tourists to come to the Sabang.

\subsection{Sabang Port As Sabang Port}

Sabang as a free trade area and free port gives its own color to the lives of its people. The livelihoods of the people in general are as clove farmers and coconut farmers and fishermen. Then in general Sabang residents engaged in trading business, namely by utilizing free trade and free ports of Sabang.

As a result of the slightest type of livelihood of his society, it would have exerted influence on the narrowness of jobs available to the people of the Sabang. Without this then the Sabang would be deserted than the trade and stopover of ships wishing to sail in the Indian Ocean bound for Europe as well as other countries.

In addition Sabang was granted free Port status and free trade due to government policy, but other reasons were due to confrontations between Indonesia with Malaysia. The confrontation between Indonesia with Malaysia and Singapore led to Sabang's opening of free port status and free trade areas in order to be refuted by ships carrying goods from both Hongkong, Japan and Taiwan. The pits were as if it would replace the position of Japan or the

\footnotetext{
${ }^{4}$ Sjamsuddin Mahmud, et al., 1967 Free Port of the Sabang, Banda Aceh: KITLV, 1968, p. 6-7.

${ }^{5}$ Ibid., p.6-7.

${ }^{6}$ M. Yusuf Rangkuti, "Sabang (1945-1965)”, Skripsi-S1 unpublished, Medan: North Sumatra University, 1986, p. 44-45.

${ }^{7}$ Ibid., p. 15-16
} 
bustling Singapore ports overrun by ships sailing in the Indian Ocean and carrying merchandise for market in Asia. Its purpose is that Sabang's free port can rival Singapore's transito port.

In the 1960s until with 1965 Indonesia was isolated from the International world, even out of members of the United Nations (Union of Nations). In 1965 due to the situation of Indonesia's very poor state resulting from a sway or domestic unrest that caused bloodshed between brothers or between existing parties in Indonesia. The Communist Party of Indonesia (PKI) is one of the dominant political forces, hence rampant within Indonesian rule as well as taking part in determining the wisdom of the government. As a result the social, economic and political circumstances in Indonesia are getting worse which long time has been more fertile. This made the advantage too for the PKI to instill its power within the body of the Indonesian government.

The Sabang during the time of the Ledged Economy and Led Democracy was experiencing circumstances in contrast to the other regions that existed in Indonesian territory. Thebang grew crowded with oeh incoming ships carrying goods free of these duties and excise, resulting in a flood of foreign goods in the Sabang market and crowded traders coming from outside the Sabang to hold a buying transaction of goods. This is in accordance with the predicate of the status of Sabang port as a free trade area with its free port. Yet the purchasing power of such a low society was due to high inflation at the time.

This inflation rate was up to $600 \%$ so people's economic life was already very low income ${ }^{8}$. The staple-needs items that are especially like rice and sugar are already unaffordable to the community anymore because of their so high price. Although in the Sabang many imported goods entered but the buyer's power was still lacking and these goods were heavily stockpiled or speculated by merchants to wait for the market situation to improve, only to be marketed by merchants.

The economic situation is getting worse so it has caused Indonesia's foreign political situation to already lean toward the communist bloc, especially with the PRC (People's Republic of China) as well as augmented confrontations with Malaysia and Singapore it has required enormous costs. The government turned the people's attention away from the deteriorating economic state to a confrontation attempt with Malaysia. Besides that Indonesian relations with China were getting closer and anti-Americans were increasingly becoming-so. In this time the Sabang became a free trade area experienced ups and downs in trade due to the fierce situation of domesticity.

Alongside the occurrence of conphrontation with Malaysia, the existence of Sabang free port opening venture, in March 1963 by a research team of the Economic and Social Research Institute (LPES) of the Faculty of Economics of Kuala Shia University in collaboration with the combined export entrepreneur Sumatra made research on the possible reopening of Sabang as a free port. On the basis of that study, the Aceh Government urged the central government in Jakarta to reopen the status of the Sabang as a free port. To coincide with the political situation Indonesia is confronting Malaysia and Singapore, and the act of breaking off any economic ties with Malaysia and Singapore in September 1963, had led to the accelerated designation of the Sabang as a free port as a continuation of the recommendations being processed at that time by the central government.

${ }^{8}$ Sartono, op.cit., p. 110. 
It then formed Komando Tertinggi Operasi Ekonomi (KOTOE) meaning government that held an important role in economics. ${ }^{9}$ On 16 October 1963 with the determination of the President of the Republic of Indonesia No. 10 of 1963 the Sabang was designated a free port (free port) with implementation handed over to Komando Tertinggi Operasi Ekonomi (KOTOE). After the president of the Republic of Indonesia designated Sabang Port to be Free Port (free port), No. 10 in 1963, the 16th of October 1963 and the implementation was handed over to Komando Tertinggi Operasi Ekonomi (KOTOE). By bringing together the COTOE into KOGAM (Komando Operasi Ganyang Malaysia) then subsequent management of Sabang Free Port is regulated by KOGAM. Once the confrontation with Malaysia was terminated, KOGAM itself was no longer needed, so this project was later under the Chairman of the Combined V KOTI (Komando Operasi Tertinggi). With the disbandment of KOTI, then now the Free Ports Project of the Sabang under the Minister of State for Economic Affairs of Finance and Industry. ${ }^{10}$

As it is known that Sabang has developed based on Presidential Establishment No. 10 Years 1963 and Presidential Regulation No. 22 Year 1964, for 6 more years the Sabang has developed as one of the Leverage Centres of National Economy, in particular the economy of its hinterland regions, without an objective warranty protected by law. ${ }^{11}$

Connecting with the re-establishment of the Sabang as a free port, then the Government has increased the status of Sabang government as a Free Port, becoming a Level II Region of Sabang Township with Act No. 10 of 1965 on June 14, 1965. Further since the passage of Act No. 18 Year 1965 on the Principals of Local Government, hence the Municipality designation changed to Sabang Municipality. ${ }^{12}$ In 1967 in organizing the Sabang free port construction project had been formed a body called the Sabang Free Port Project Development Managing Command (KP4BS). The agency is tasked with organizing the construction and is responsible for the implementation of the Sabang free port project's builders, as mentioned above.

To hold the final preparation, then on 25 June 1969 arrived at the Sabang one troupe numbering 26 people consisting of a government team chaired by Prof. Dr. Subroto with a total number of 12-person members, and a House-GR team chaired by M. U.S. eunuchs with a total of 12-person members. Such circumstances reached their peak when on 23 December 1969 President Soeharto and several other ministers and state officials visited Sabang. Finally, on March 27, 1970, came out Act No. 3 Year 1970 on the staple provisions of free trade areas and free ports, and Act No. 4 Year 1970 about the free trade area with the free port of the Sabang. ${ }^{13}$

Since 1970 the Sabang struggle entered a new phase. The draft law governing on the status of the long-stacked Saves has been submitted by the house of representative-GR ${ }^{14}$, namely by the exit of law No. 3 Year 1970 on the staple provisions of free trade areas and free ports, and the No.4 Act of the Year 1970 on free trade areas and Free ports of the Sabang. ${ }^{15}$

\footnotetext{
${ }^{9}$ Mr. Soepardo, et al., Man and New Society of Indonesia, Jakarta: Dep. Par and Keb., 1960, p. 79.

${ }^{10}$ Sjamsuddin Mahmud, et al., 1967 Free Port of the Sabang, Banda Aceh: KITLV, 1968, p.13.

${ }^{11}$ Jusuf Walad, op. cit., p. 5.

${ }^{12}$ Anonymous, Agricultural Monography of Sabang Municipality Region, Banda Aceh: People's Agricultural Service of Aceh Privileges, 1977, pp. 10.

${ }^{13}$ Shabri A., Migration and Community Plurality in Sabang City, Banda Aceh: Banda Aceh Historical and

Traditional Value Study Hall, 2002, pp. 44

${ }^{14}$ House of Representatives - Gotong Royong.

${ }^{15}$ See attachment VII.
} 
In the free port of the Sabang and the entire Weh archipelago there are some managements that co-host its activities, namely: (1) Komando Pelaksana Pembangunan Projek Pelabuhan Bebas Sabang (KP4BS), (2) Kotamadya Sabang, (3) Komando Sub Maritim Pangkalan Angkatan Laut (Ko-Submarlanal 102), dan (4) Penguasa Pelabuhan (Port Authority). All those management activities concerning the construction of the Sabang as Free Port are coordinated by KP4BS. The free trade area with Sabang's free port in its efforts to gain part of the international transhipment trade had shown progress in $1970 .{ }^{16}$ The function of the Sabang as a transito trading centre and gateway in international trade traffic, is growing in importance. Trade developments suggest that it has increased. The number of turnovers has increased in 1970 since the opening of Free Trade Areas and Free Ports of the Sabang.

The main production in the Sabang is copra. The inhabitants of the Sabang as a whole live off coconut farming. Approximately $80 \%$ of them are small farmers with an average agricultural area of two acres in area, 9\% consisting of medium farmers with an average agricultural area of 10 acres and only $1 \%$ of which is large farmers with 21 acres of agricultural acreage. During 1967, until the end of September, according to figures from KP4BS had exported as much as $778,400 \mathrm{~kg}$ of copra yields from the island of Weh itself at a price of no less than US\$80,000. This number turned out to include roughly $73 \%$ of the entire number of Sabang production exports for 1967. ${ }^{17}$ Clove production occupies the number two spot of the entire export goods production after copra. Compared to coconuts, cloves constitute agricultural crops that have existed since the Dutch era of the Weh islands, namely began to get farmers' attention back since these ten years of carving. Thanks to its fertile soil, especially to areas whose soils come from volcanic rocks as well as suitable rainfall, hence on the island of Sabang have developed clove plant. ${ }^{18}$ The area of clove plants in the Sabang is estimated at $1,000 \mathrm{Ha}$, with production for 1980 of about 400 tons of dry cloves. With an average price of $\mathrm{Rp} 8,000 / \mathrm{Kg}$, then the agricultural sector's gross acceptance of clove yields for 1980 was 2 billion dollars, or about Rp 134 thousand per-capita, before being reduced by production costs that were in the form of shrinkage, medicine and seedlings. With the magnitude of income gained from these clove yields, it would give its own meaning to the economic and social life of this not-so-wide island. It is also the cause, that the standard of living in the Sabang, is higher than those of the cities of mainland Aceh. ${ }^{19}$

Capuches and betel nuts, although they are export materials every year, but not an important agricultural produce. The results exported from this island of Weh correspond to its agricultural income in the villages. Of the data that has been collected indicates, that of the entire agricultural acreage $79 \%$ constitute coconut farming. Cloves and other perennials include an area of $8 \%$ of all agricultural acreage, $5 \%$ rice and palawija crops (bananas, fruits and vegetables) of $8 \%$. This provides an overview of the relationship between agricultural land use, the extent and income of year-old farmers as well as the percentage of farmers' income sources of each type of agricultural venture in the villages. ${ }^{20}$

\footnotetext{
${ }^{16}$ After the passage of Laws No. 3 and No. 4 of the Year 1970.

${ }^{17}$ Sjamsuddin Mahmud, dkk., op.cit., p. 40.

${ }^{18}$ A.Kruijt, Poeloe Weh : Waarom Staats-Exploitatie Van Dit Eiland Af Te Keuren Is, s-Gravenhage: LOMAN \& FUNKE, 1897, p. 14.

${ }^{19}$ Jusuf Walad., op.cit., p. 28.

${ }^{20}$ Central Bureau of Statistics, op. cit., p. 5.
} 
Much of the farmers' attention is only to coconut crops because of this which is thought to guarantee $90 \%$ of all income sources from agriculture, then Weh island is not self-producing in the living needs of its daily population. Most of the principal living needs had to be brought in from elsewhere, especially from the Aceh mainland. Including those brought to the most vital ingredients such as rice, meat, eggs and spices. Even often also typed vegetables need to be brought in from Banda Aceh. It illustrates how dependent the Sabang city was to the income of staple-needs materials and comparisons of some important ingredient prices in the Sabang and Banda Aceh markets at the end of 1967. Not included vital needs materials from outside are fish and a few sorts of fruits, especially bananas and papayas. ${ }^{21}$

Weh Island can cover its fish needs without including fish from the outside. This is evident because $100 \%$ of the fish consumed in the Saves were produced alone by Weh island fishermen and there was no drastic price difference between wet fish in Banda Aceh with in the Saves. According to the report of the Sabang Municipal Fisheries Service there were 877 fishermen on the Weh islands in 1967. Of these all the fishermen 650 people are fixed fishermen. The rest are all-time fishermen. Fishing was done by boat, trawler, mesh, cradle, net and fishing line, in 1967 giving the fish production yield as much as approximately 460 tons or roughly 1.3 tons per day. ${ }^{22}$

In forest production, Sabang has also not been able to cover its needs. The building materials still depend on the mainland of Aceh. The natural results that exist in the Sabang, most of them used as an everyday interest. The pits of this time were still not considered to be industrial areas and are still in terms of providing services in commerce. This was due to the beginning of the establishment of a Free port of the Sabang and free trade, the region was still a stage of policy formation and had not been poured in the form of the Act. The trade sector is the most major and important business field in the Sabang in the increase in revenue of this area.

Therefore, the short-term objectives that are intended to be achieved in order to increase the activities of overseas exports (and imports from the hinterland area) are improvements to the transport and communication system that contacts the gateway of the Sabang with other gateways contained in the hinterland area. Reviewed from the port of origin of imported goods from Indonesian Customs Region, for 1965 imports were only carried out through the ports of Ulee Lheue, Lhokseumawe, Meulaboh and Tanjung Priok. More than 50\% of the import-values were carried out through the port of Ulee Lheue. In 1966 holding an important role was the port of Volunteer (US\$1,696,535.02 =28\%), then following Lhokseumawe (US\$1,069,528,11 $=18 \%$ ), Ulee Lheue (US\$832,830.64 = 14\%) and Pontianak (US\$654,108.114=11\%). In 1967 the role of the port of Belawan as the port of import origin had been reduced, imports mainly coming from the port of Ulee Lheue (US\$809,415.50 = 25.2\%), Lhokseumawe (US\$647,860.26) and Kuala Langsa (US\$635,741.16). Imports originating from the Against port are only US\$242,935.99.

Another important port of import origin is Meulaboh with the values of the port. Sinabang (US\$136,330.73) and the island of Nias/Mount Sitoli (US\$134,497,24) located along the West coast of the island of Sumatra. As it is known through Kuala Langsa ports mainly issued rubber and coffee, from Lhokseumawe copra, coffee and betel nut and through Meulaboh port are palm/intisawit and rubber. The export commodity of the Sabang Port is largely dominated by

\footnotetext{
${ }^{21}$ Interview with Ilyas in Sabang, May 2017

${ }^{22}$ Sjamsudin Mahmud, dkk., op.cit., p. 41.
} 
the Plantation's results. As for the commodities produced from the plantation's produce were both the result of plantations as well as the farming of the people. Other commodities are forest yields, fisheries and others. As for the commodities of the plantations as well as the farming of the people were cloves, pepper, coffee, copra, tea, rubber. The commodities of the forest yield are fruits, such as betel nut, frankincense, sweet skin, kapuk, emping, yellow nuts and so on. The fishery sector is an undisputed thing in Sabang Port, commodities of processed fish yields such as wet fish and others. As well as other commodities namely the oil of the patcholine, the bark of the mane, lead, live goats, live buffalo, snakeskin, cowhide, sulfur, batik cloth, and so on. ${ }^{23}$

The import commodity of the Port of the Sabang is a much-needed item for daily life or primary and secondary needs, although there are also some tertiary needs. In addition to the daily necessities of life, commodities imported into Sabang Port take the form of necessities as well as plantation and agricultural equipment and supplies. Primary need-needs are rice, sardines, butter, cheese, biscuits, milk, fish, and others. As for the complementary or secondary needs of items imported through the Port of the Sabang are wire-initial manufactured goods, nails, iron, cement, triplek or plate, as well as tooling of household tools, iron, reddish clothing, and others. ${ }^{24}$

The magnitude of export and import value impacted the advance of shipping in Sabang Port. As a port, the island of Sabang lies within a network of already formed marine linkage routes and lies at the gateway of the Strait of Malacca. The voyages carried out in Sabang Port can be divided into two types of inter-shore shipping and inter-island and international shipping International and inter-island voyages conducted from Sabang Port carried shipping activity from Sabang Port to the existing islands around Sumatra Island such as Java Island, Borneo and the existing small islands of Riau Islands, whereas international cruises made from Sabang Port were made from Penang Sabang Port, Singapore, Malacca and Europe. These voyages were generally export and import cruises to transport plantation produce delivered to various existing countries of the Americas and Europeh and bring in goods from other countries, and stopover ships taking or filling drinking water in the Sabang, as well as cruises against passengers between Balohan and Ulee-Lheu.

The voyages above, if the harvest time of the plantation's produce arrives, then Sabang Port is always busy visiting the ships. Not only was it preoccupied with trading ships but preoccupied also with passenger ships. To serve the interinsular passenger and freight flow (mainly Ulee Lhee - Balohan) operated several pieces of ships generally managed by P.T. Weh Shipping Island Coaching. On average the number of passengers per-month transported by P.T. The coaching of Weh Shipping Island was 11,001 up and 11,868 down. However according to the information obtained there are about $10 \%$ additional passengers either using a note or other way. It is estimated that for 1981 at least there will be about 500 people up and 500 people down per day traveling between Balohan - mainland Aceh.

\footnotetext{
${ }^{23}$ Djamaluddin, op.cit., p. 43.

${ }^{24}$ Ibid., p. 28-31
} 


\section{Conclusion}

Georaphically, the port of Sabang was originally simply an area considered an exile area or as a place for people deemed to be detrimental to Dutch rule. Gradually the Dutch government began to pay attention to the Sabang because it had a very strategic geographical Sabang, and had a fine natural structure, had good spring sources, as well as a tropical climate. The pits were lyrified by the Dutch party with regard to the opening of the Suez Canal in 1869 . The path provides a road from Laut Tengah to Laut Merah. Steamships from Europe could take a much safer and shorter route towards Asia. Later, ships coming towards Southeast Asia were approached from the sea via the Strait of Malacca and not through the Sunda Strait from the southwest. Towards the end of the nineteenth century, the Malacca Road became very important as the main sea route for all ships on their way to Asia. The ship passing through the Suez Canal to India first reached Sumatra. Due to this road shift, Sumatra became a thing of value to the Dutch and made the Sabang a strategic place.

Coal became the most major thing of all time the Sabang. The port was also the beginning of the development of a city. The pit is also a thriving area beginning with export and import trade. However, seeing the dynamics occurring starting from the time of the Netherlands, Japan which made the Sabang as the place where the region defended itself from outside threats, until the time of independence, the Sabang port was still experiencing ups and downs against its development. This Free Port of the Sabang if it is re-employed to become a thriving Free Sabang port due to import export trade, it will be very difficult if viewed from other free port competitions. However, Sabang has a very beautiful nature, it can be used to establish Sabang as a tourism region to further develop. The Sabang Port is threatened several times its existence through various developments, due to competition from new ports such as the Belawan, Batam, through world wars. For a long time, the Sabang were able to adapt and evolve.

\section{References}

The Republic of Indonesia Presidential Regulation Act Number 22 of 1964. The Republic of Indonesia Presidential Regulation Act Number 23 of 1964. Republic of Indonesia Act Number 4 of the Year 1970.

The Presidential Decree Act of the Republic of Indonesia Number 41 Years 1973.

Republic of Indonesia Act Number 10 Years 1985.

Anonim, Sabang Sebagai Daerah Pariwisata, Sabang: Proyek Pengembangan Kotamadya Daerah Tingkat II Sabang, 1984. , Monografi Pertanian Daerah Kotamadya Sabang, Banda Aceh: Dinas Pertanian Rakyat Daerah Istimewa Aceh, 1977. , Sabang Bay Harbour and Coal COY. Ltd. Sabang (Nort Sumatra), Amsterdam : J.H. De Bussy, tanpa tahun.

Lapian, Adrian B, Pelayaran dan Perniagaan Nusantara Abad ke-16 dan 17, Jakarta: Penerbit Komunitas Bambu, 2008.

Badan Statistik Sabang, Sabang Dalam Angka Tahun 1976, Sabang: Tanpa Penerbit, 1976. , Sabang Dalam Angka Tahun 1978, Sabang: Tanpa Penerbit, 1978.

Biro Pusat Statistik Sabang, Sabang Dalam Angka 1981, Sabang: Kantor Statistik, 1981. 
Departemen Pendidikan dan Kebudayaan, Sejarah Daerah Provinsi Daerah Istimewa Aceh, Jakarta: Balai Pustaka, 1977/1978.

Departemen Pendidikan dan Kebudayaan, Aspek Geografi Budaya dalam Wilayah Pembangunan Daerah Istimewa Aceh, Jakarta: Departemen Pendidikan dan Kebudayaan,1983.

De Boer, M.G, Zeehaven en Kolenstation Sabang 1899-1924, Amsterdam : vervaardigd door L.Van Leer \& CO, 1924.

Djamaluddin, Daerah Perdagangan Bebas Dengan Pelabuhan Bebas Sabang 1970, Sebuah Supplement Terhadap Pelabuhan Sabang 1967, Banda Aceh : P4BS dan Fak. Ekonomi Universitas Syiah Kuala, 1971.

Gafnesia, Dahsyat, dkk., Pelabuhan Riau Hubungan dan Peranannya dengan Daerah-Daerah Hinterland Tahun 1700-1973, Tanjungpinang: BPSNT - Depbudpar, 2007.

Groneman, J, Is Sabang Gezond, Jogyakarta : W. A. VAN DEB HUCHT \& Co, 1904.

Hardi, Daerah Istimewa Aceh, Latar Belakang Politik dan Masa Depannya, Jakarta: Cita Panca Serangkai, 1993.

Kruijt, J.A, Poeloe Weh : Waarom Staats-Exploitatie Van Dit Eiland Af Te Keuren Is, sGravenhage: LOMAN \& FUNKE, 1897.

Krusemann, Bart, "Sabang: Haven In De Rimboe Analyse Van Een Kolenstation En Zeehaven In 1890-1941”, Tesis-S2 belum diterbitkan, Amsterdam : Universiteit Leiden, 2015.

Leur, J.C. Van, Indonesian Trade and Society, Bandung : Sumur Bandung, 1960.

Lindblad, J. Thomas, Fondasi Historis Ekonomi Indonesia, Yogyakarta: Pusat Studi Sosial Asia Tenggara UGM dan Pustaka Pelajar, 2002.

Ling, Ooi Giok, et al., Beyond The Port City Development and Identity in $21^{\text {st }}$ Century Singapore, Singapore : Prentice Hall, 2004.

Mahmud, Sjamsuddin, et al., Pelabuhan Bebas Sabang 1967, Banda Aceh : KITLV, 1968.

Mededeelingen en rapporten, Havenwezen no. 5 Nederlandsch-Indische Haven, Batavia, 1920.

Menno, S, Antropologi Perkotaan, Jakarta : Raja Grafindo Persada, 1991.

Murphey, Rhoads, On Evolution of the Port City, dalam Frank Broeze (ed.), Brides of the Sea: Port Cities of Asia from the 16 th -20 th Centuries, Kensington: New South Wales University Press, 1989.

Rahman, Albina A., Sabang (Dalam Lintasan Sejarah), Sabang: Sabang Heritage Society, 2015.

Sasono, Herman Budi, Manajemen Pelabuhan dan Realisasi Ekspor Impor, Yogyakarta: Cv. Andi Offset, 2012.

Shabri. A, et al., Migrasi dan Pluralitas Masyarakat di Kota Sabang, Banda Aceh: Balai Kajian Sejarah dan NIlai Tradisional Banda Aceh, 2002.

Shadily, Hasan, Ensiklopedia Indonesia, Jilid 7. Jakarta: PT Ichtiar Baru van Hoeve, 1999.

Soepardo, Mr., et al., Manusia dan Masyarakat Baru Indonesia, Jakarta: Dep. Par dan Keb., 1960.

Sudirman, et al., Sejarah Pelabuhan Ulee Lheue, Banda Aceh : Balai Pelestarian Sejarah dan Nilai Tradisional, 2007.

Triatmodjo, Bambang, Pelabuhan, Yogyakarta : Beta Offset, 1996.

Walad, Jusuf, dkk., Pelabuhan-Pelabuhan di Daerah Istimewa Aceh, Banda Aceh : Unsyiah, 1967.

, Daerah Perdagangan Bebas Dengan Pelabuhan Bebas, Banda Aceh: Lembaga Penyelidikan Ekonomi dan Sosial Fakultas Ekonomi Unsyiah, 1978/1979. 